\title{
INTERNALISASI METODE HAFALAN AL-QUR'AN DALAM TRADISI SALATT TAQWIYAH AL-HIFZH (Studi Living Hadits Di Pondok Pesantren Usyaqil Qur'an Talangsari Jember)
}

\author{
Siti Nur Azizatul Luthfiyah dan M. Khoirul Hadi al-Asy'ari \\ Institut Agama Islam Negeri (IAIN) Jember \\ azizah.4ja@gmail.com dan arimoh16@gmail.com \\ Diterima 1 Juni 2019 | Direview 15 Juni 2019 | Diterbitkan 27 Juni 2019
}

\begin{abstract}
:
Memorizing the Koran becomes a part that is not released from the guarding of Allah SWT towards the authenticity of the Qur'an. However, the method of memorizing the Koran did not receive special attention and priority in the authoritative texts of the Islamic religion even though at the same time the authoritative texts, - especially the hadith, explained a lot of small and trivial matters. But PP. Usyaqil Qur'an has one of the traditional rituals relating to memorizing the Qur'an, - which are not practiced by many memorizers of the Qur'an elsewhere. Furthermore, they rely on the tradition to the Prophet. To that end, the author will examine the traditional phenomenon șalat taqwiyah al-bifich as one of the hadith phenomena which the community has lived (living hadith) in order to know the practice of the prayer tradition and to know their understanding of the foundation of the prayer. The phenomenology approach, interview method and observation were chosen by the researcher to find out directly the implementation of the tradition based on the perspective of the research object.
\end{abstract}

Keyword: Salât taqwiyah al-hifæ̧, Living Hadits, Internalisasi

\begin{abstract}
Abstrak:
Menghafal al-Quran menjadi bagian yang tidak terlepakan dari penjagaan Allah SWT terhadap keotentikan al-Qur'an. Kendati demikian, metode menghafal al-Quran tidak mendapat perhatian secara khusus dan prioritas dalam teks-teks otoritatif agama islam padahal di saat yang sama teks-teks otoritatif tersebut,- terutama hadits banyak menjelaskan hal-hal yang kecil dan remeh. Namun PP. Usyaqil Qur'an memiliki salah satu ritual tradisi berkaitan dengan menghafal al-Qur'an,-yang tidak. diamalkan oleh kebanyak penghafal al-Qur'an di tempat lain. Lebih lanjut, mereka menyandarkann tradisi tersebut kepada rasulullah. Untuk itu, penulis akan meneliti fenomena tradisi șalat taqwiyah al-hifžb sebagai salah satu fenomena hadits yang dibidupkan masyarakat (living hadits) guna mengetahui praktik tradisi shalat itu dan mengetahui pemabaman mereka terhadap landasan pelaksanaan shalat tersebut. Pendekatan fenomenologi, metode interview dan observasi dipilih peneliti untuk. mengetabui secara langsung pelaksanaan tradisi tersebut berdasarkan perspektif objek penelitian.
\end{abstract}

Kata Kunci: Salât Taqwiyah al-hifžh, Living Hadits, Internalisasi

\section{Pendahuluan}

Salah satu fenomena yang tidak pernah surut dan menjadi salah satu karakteristik umat islam atas umat agama-agama lain adalah antusiasme muslimin dalam menghafal al-Quran maupun hadits. Hal ini membuktikan kebenaran janji Allah dalam QS. Al-Hijr 9 bahwa Ia akan senantiasa menjaga otentisitas al-Quran. Walaupun Allah telah menjanjikan bahwa Ia akan memudahkan orang-orang yang mau mempelajari dan menghafal al-Quran tetapi tidak dipungkiri bahwa menghafal kitab setebal itu akan membutuhkan beberapa metode yang sesuai dengan karakter masing-masing orang demi mempermudah proses hafalan tersebut. Namun di titik ini, al-Quran tidak memberikan gambaran secara langsung mengenai proses dan cara menghafalnya.

Rasulullah secara pribadi pun juga tidak menunjukkan secara gamblang metode yang harus digunakan seseorang dalam menghafal al-Quran. Hadits-hadits yang berkenaan dengan hafalan al-Quran berkutat pada beberapa hal saja misalnya, pertama, Kemuliaan belajar dan mengajar al-Quran, kedua, Motivasi tentang kemuliaan pembaca dan penghafal al-Quran ketiga, Perintah menghormati ahli al-Quran keempat, Peringatan bahwa al-Quran akan mudah terlupakan jika tidak diiringi dengan proses murajaah yang intens.

Demikian pula riwayat dari sahabat dan tabi'in juga kurang memberikan penjelasan secara rinci metode yang harus ditempuh seseorang saat menghafal al-Quran. Walhasil, karena islam tidak memberikan aturan pakem mengenai metode yang harus ditempuh 
seseorang dalam menghafal Al-Quran maka masing-masing pribadi berhak menentukan metode manapun yang sesuai dengan karakter dan kemampuannya. Namun hipotesis bahwa rasulullah tidak menunjukkan manhaj menghafal al-Quran kepada umatnya tidaklah sepenuhnya benar menurut hemat penulis. Karena begitu banyak hal kecil yang Rasulullah perhatikan dalam kehidupan umatnya. Misalnya anjurannya untuk memperbanyak kuah saat memasak daging, anjuran makan dari bagian tepi, anjuran berdehem sejenak sebelum istinja' dan hal-hal kecil lainnya. Sedangkan menghafal al-Quran adalah salah satu manifestasi dari penjagaan Allah terhadap al-Quran yang merupakan sumber hukum utama dalam islam. Oleh karena itu, perihal hafalan al-Quran menempati posisi yang urgen dalam islam. Maka bagaimana mungkin Rasulullah tidak memperhatikan hal yang penting namun di saat yang sama ia mengujarkan hal-hal kecil.

Kegelisahan akademis tersebut kemudian menemukan sedikit jawaban saat peneliti mengetahui bahwa ada kelompok tertentu, salah satunya yaitu PP. Usyaqil Qur'an Talangsari Jember, yang melakukan salah satu ritual khusus dalam rangka membantu hafalan al-Quran dan mereka menyandarkan ritual tersebut kepada rasulullah SAW (me-marfu'-kan) yang tidak diamalkan oleh banyak kelompok-kelompok bahkan lembaga-lembaga tahfizh al-Qur'an. Ritual tersebut dilaksanakan dalam bentuk shalat yang disebut sebagai șalât taqwiyah al-hifž̉ sebagai salah satu upaya PP. Usyaqil Qur'an menghidupkan sunnah yang mereka yakini terkait cara menguatkan hafalan al-Qur'an. Sunnah atau hadits yang dihidupkan dalam masyarakat atau respon mereka terhadap suatu hadits inilah yang disebut sebagai living hadith Tradisi praktik dalam living hadis ini cenderung banyak dilakukan oleh umat islam. Hal ini di dasarkan atas sosok Nabi Muhammad dalam menyampaikan ajaran islam,sehingga masih menjadi kajian menarik dan belum banyak tersentuh dibanding penelitian-penelitian hadits lainnya. Oleh karena itu, peneliti akan menyajikan hasil kajian tertarik untuk mengkaji landasan pelaksanaan, prosesi sekaligus kaitannya ritual tersebut dengan proses menghafal al-Qur'an. ${ }^{1}$

\section{Kontektulaisasi Hadist: Șalât Taqwiyah Al-Hifzh Dalam Pandangann Hadist}

Dalam mendefinisikan tentang arti kata shalat, Imam Rafi'i mendefinisikan bahwa shalat dari segi bahasa berarti do'a, dan menurut istilah syara' berarti ucapan dan pekerjaan yang dimulai dengan takbir, dan diakhiri/ditutup dengan salam, dengan syarat tertentu. Taqwiyah adalah isim masdar dari kata qawaa, yang memiliki arti "penguat atau menguatkan" adapun bifz $b i$ berarti "hafalan". Jadi yang dimaksud dengan taqwiyatul bif ₹̧ $h i$ adalah penguat hafalan.

Sholat taqwiyatul hifž hi adalah sholat yang diajarkan Nabi Muhammad SAW. Kepada shahabatnya yaitu Ali bin Abi Thalib untuk menjaga hafalan Al-Qur'an nya yang terlepas dari ingatannya. Hadist tentang Sholat taqwiyatul hifz $h i$ ini muncul berkenaan dengan keluhan sahabat Ali bin Abi Thalib yang tanpa sengaja lupa terhadap hafalan alqur'an yang telah dihafalnya. Seperti diceritakan dalam hadist berrikut ini:

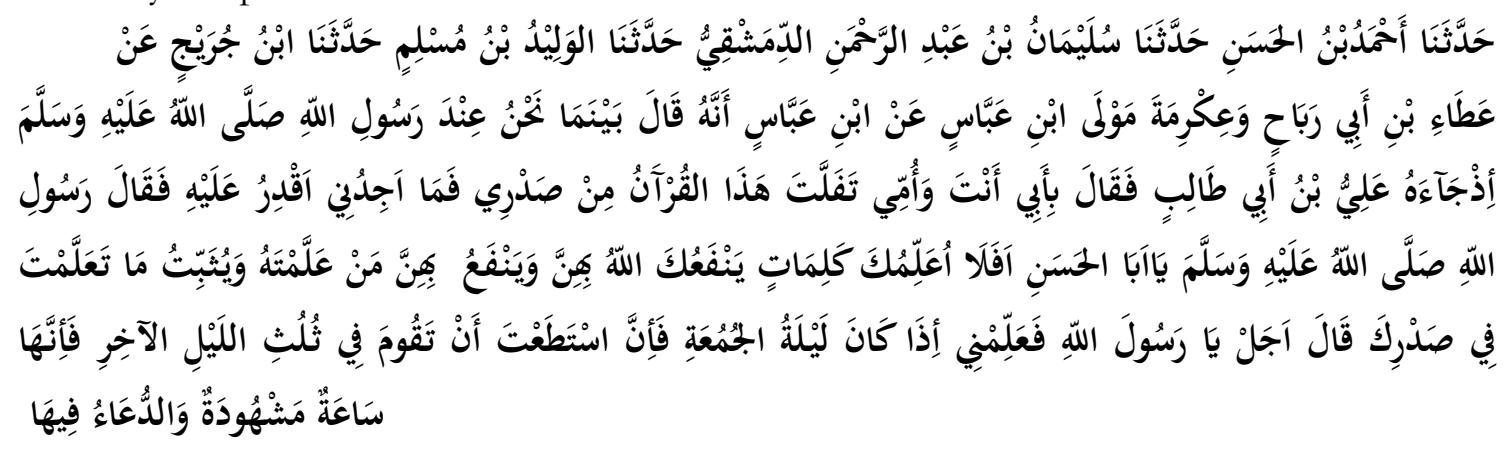

${ }^{1}$ Herry, Bahirul Amali, Agar Orang Sibuk Bisa Menghafal Al-Qur'an. (Yogyakarta: Teras, 2012), h. 45 
Artinya: "Dari Ibnu Abbas beliau berkata: Ketika kami sedang duduk disisi Rasulullah SAW, tiba-tiba datanglah Ali bin Abi tholib ra, ia lalu berkata: "Demi ayah dan ibuku! Al-Qur'an ini telah terlepas dari dadaku, maka aku tidak menemukan diriku mampu menguasainya".

Rasulullah SAW lalu berkata: "Wahai Abal Hasan, maukah kau kuajari beberapa kalimat yang dengan kalimat ini Allah akan memberikan kemanfaatan padamu, dan orang-orang yang kau ajari kalimat itu, dan mengukuhkan apa yang kau pelajari dalam dadamu?". Sahabat Ali menjawab: "Ya, wahai Rasulullah, ajarilah aku!". Rasul bersabda: "ketika malam jum'at, kalau kamu mampu untuk bangun pada 1/3 malam yang akhir (maka bangunlah), karena sesungguhnya waktu itu adalah waktu yang disaksikan, dan berdo a pada waktu itu sangat mustajab. Bahkan saudaraku Ya'qub berkata kepada putranya; "Aku akan memintakan ampun kalian pada tuhanku", ia berkata (demikian) sampai datanglah malam jumat. Jika kamu tidak mampu maka (bangunlah) pada tengah malamnya, jika kau tidak mampu juga maka pada 1/3 malam yang awal, kemudian shalatlah empat raka'at, pada raka'at pertama membaca Fatihah dan (surat) Yasin, pada raka'at kedua membaca Fatihah dan Haamim (surat) Ad-Dukhon, pada raka'at ketiga membaca Fatihah dan Alif lam mim Tanzil (surat) As-Sajdah. Pada raka'at keempat membaca Fatihah dan Tabarok Al-mufashol (surat Al-Mulk). Lalu ketika kau telah selesai dari tasyahhud (tahiyyat akhir) maka pujilah Allah dan baguskanlah pujian pada Allah, dan bersholawatlah kepadaku dan baguskanlah, juga kepada nabi-nabi yang lain, dan mintakanlah ampunan bagi mukminin dan mukminat dan juga bagi saudara-saudaramu yang telah mendahului kamu dengan iman kemudian berdo `alah pada akhir hal itu :

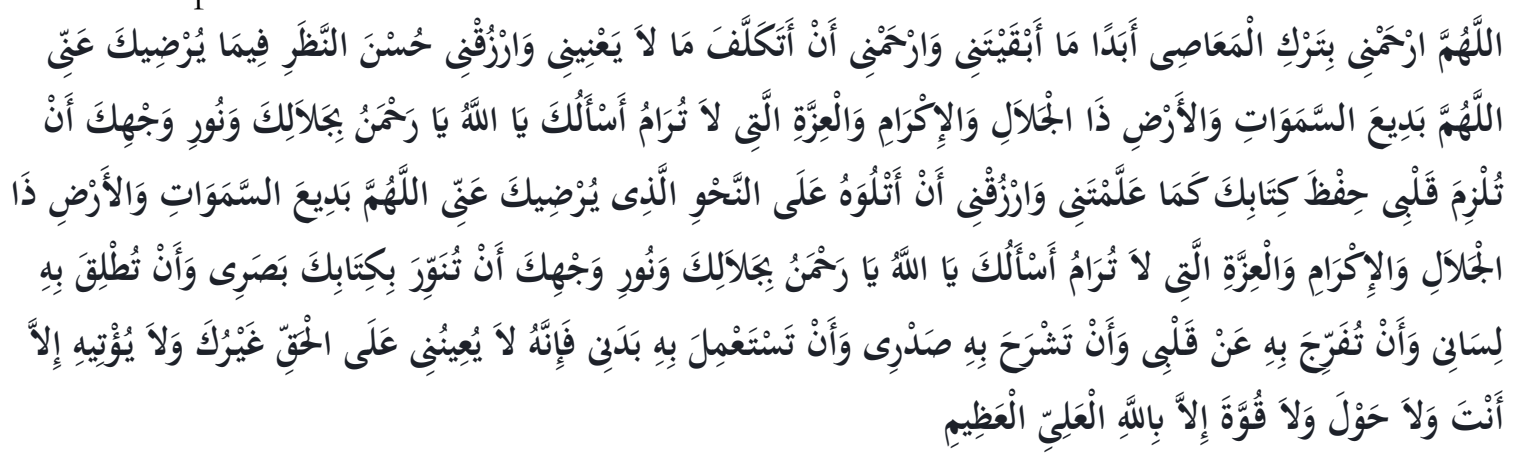

Artinya: "Ya Allah, kasibinilah aku dengan bisa meninggalkan maksiat selamanya selagi Engkau menetapkanku (selama bidupku), dan kasibinilah aku dari melakukan perkara yang tidak. berguna bagiku, dan berikanlah aku baiknya penglihatan kepada perkara yang membuat Engkau ridho kepadaku. Wahai Allah yang menciptakan langit dan bumi, yang mempunyai keagungan, kehormatan dan kemuliaan yang tidak dapat dicapai (oleh makbluk), aku memintamu Ya Allah.... Ya Rahman... demi keagungan-Mu dan cahaya Dzat-Mu agar Engkau menetapkan batiku untuk. bisa menghafal kitabMu sesuai dengan yang Engkau ajarkan padaku, dan berikanlah aku pertolongan untuk membaca kitabMu sesuai dengan cara yang membuat-Mu ridho padaku. Wahai Allah, Pencipta langit dan bumi yang mempunyai keagungan, kehormatan dan kemuliaan yang tidak dapat dicapai (oleh makbluk), aku meminta kepada-Mu Ya Allah.... Ya Rabman... agar Engkau menyinari penglihatan batinku dengan kitab-Mu, agar Engkau membuat lisanku berucap dengannya, dan agar Engkau bilangkan dengannya kesusahan dari hatiku dan Engkau lapangkan dengannya dadaku, dan agar Engkau membuat tububku mengamalkanya karena sesunggubnya tidak ada yang mampu menolongku kepada kebenaran kecuali Engkau dan tidak ada yang mampu mendatangkanya kecuali Engkau. Tidak ada daya dan upaya selain dari Allah yang maha tinggi lagi maha agung".

"Wahai Abal Hasan engkau lakukan itu dalam tiga jum`at, lima atau tujuh, maka engkau akan dikabulkan dengan izin Allah. Dan demi dzat yang Allah mengutusku dengan kebenaran. Aku tidak pernah menyalahi seorang mukmin sama sekali.". Ibnu Abbas berkata: "maka demi Allah, tidak sampai lima atau tujuh sehingga Ali datang pada Rasulullah dalam majlis yang sama lalu berkata: "Wahai Rasulullah sesungguhnya aku dahulu tidak mengambil (menghafal) kecuali empat ayat atau semisalnya, dan ketika aku membacakannya, 
ia terlepas. Dan sekarang aku mempelajari 40 ayat dan semisalnya lalu ketika aku membacakannya maka seakanakan kitab Allah ada dihadapan kedua mataku, dan dulu aku mendengarkan hadits lalu ketika aku mengulanginya, ia terlepas. Dan sekarang aku mendengar banyak hadits lalu ketika kau berucap dengannya. Aku tidak mengurangi darinya satu huruf pun. Maka Rasulullah berkata kepadanya ketika itu; "Engkan seorang mukmin, Demi pemilik Ka'bah! wahai Abal Hasan! (HR. Tirmidzi).

Al-Mubarakfuri berkata mengenai makna hadits tersebut bahwa saat itu Ali ra. atau dalam kunyah-nya 'Abu Hasan' menceritakan bahwa hafalannya terlepas dari dadanya secara mendadak tanpa adanya tenggang waktu.15 Lalu Rasulullah SAW menasehati untuk sholat dan berdoa di sepertiga malam terakhir karena waktu sepertiga malam terakhir adalah waktu yang disaksikan oleh malaikat yang ikut mendoakan dan mengaminkan doa setiap orang yang bangun di sepertiga malam terakhir. Hal meminta ampunan atau berdoa di sepertiga malam terakhir tersebut juga pernah dilakukan oleh Nabi Ya'qub as. kepada anak-anaknya, sebagaimana Rasulullah SAW menyatakan bahwa saudaranya, yakni Nabi Ya'qub as, karena sesungguhnya para nabi itu menjadi saudara bagi nabi-nabi yang lain, demikian pula istri-istri mereka dan agamaagama mereka, mereka memiliki kesatuan dalam beragama, yaitu Islam. ${ }^{2}$

Demikian pula Nabi Ya'qub as. berkata bahwa akan memintakan ampunan anak-

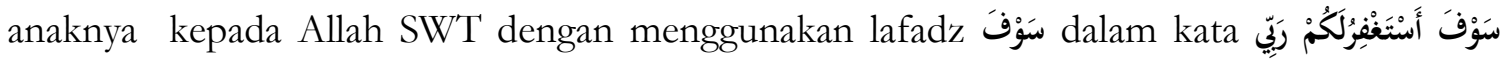
maksud Nabi Ya'kub as. Menggunakan lafadz tersebut karena Nabi Ya'kub as. Tidak langsung memintakan ampunan anak-anaknya kepada Allah SWT. Tetapi Nabi Ya'qub as. ingin mendoakan mereka secara khusus dan pada waktu yang baik, seperti di sepertiga malam terakhir dimana Allah SWT membuka seluas-luasnya pintu rahmat dan maghfirah kepada siapapun yang tulus dalam berdoa. Beliau juga menunggu sampai datangnya malam jum'at untuk memintakan ampunan kepada Allah SWT. Hal ini menunjukkan bahwa malam jum'at itu lebih utama daripada malam-malam yang lain. ${ }^{3}$

\section{Internalisasi Sholat Taqwiyatul Hafidz di Ponpes Usyaqil}

Pondok Pesantren Usyaqil Qur'an yang beralamatkan di jalan K.H Siddiq no 19 telah pindah ke jalan sunan bonang blok C sejak November 2016 lalu karena tempat yang lama sudah tidak layak untuk ditinggali. Ponpes usyaqil qur'an sendiri memiliki 23 santri yang mana keseluruhannya merupakan penghafal qur'an, sedangkan beberapa lainnya sudah boyong dikarenakan sudah menghafalkan 30 juz. Di ponpes ini hanya tersedia untuk penghafal qur'an khusus putri yang diasuh oleh Ibu Nyai Hj Nusrotud Diniyah pondok ini terletak di Kota Jember, sala satu ritual para santri adalah sholat taqwitaul hifz ${ }^{4}$ sholat ini sebagai

${ }^{2}$ Chairani, Lisya \& Subandi, Psikologi Santri Penghafal Al-Qur'an: Peranan Regulasi Diri. (Yogyakarta: Pustaka Pelajar 2010), h. 65

${ }^{3}$ Imam Nawawi Abu Zakaria Yahya bin Syaraf, At-Tibyan: Adab Penghafal Al-Qur'an, Solo: Al-Qowam. (dar al Kutub al Ilmiah: tt, 2014 ). h. 34.

${ }^{4}$ Sahabat Abdullah bin Abbas menceritakan bahwa sahabat Ali bin Abi thalib pernah mengeluh kepada Rasulullah saw. atas hafalannya yang lemah. Beliau lalu bersabda, "Wahai Ali, maukah engkau aku ajari doa, mudah-mudahan dengan itu Allah swt. memberimu dan anak didikmu manfaat? Juga hafalanmu menjadi kuat?" "Tentu, ya Rasulullah," jawab Ali senang. Rasulullah saw. lalu bersabda, "Lakukanlah shalat empat rakaat pada malam Jum'at. Pada rakaat pertama bacalah surat al-Faatihah dan surah Yaasin. Pada rakaat kedua kamu baca Haa Miim, ad-Dukhan, setelah membaca, al-Faatihah dan Alif Laam Miim Tanzil, as-Sajdah. Kemudian pada rakaat keempat surah al-Faatihah dan surat Tabarak. Jika tasyahud telah selesai, sampaikan pujian kepada Allah swt., lalu bershalawatlah atas para nabi, kemudian mintakanlah ampunan bagi orang-orang yang beriman." Beliau melanjutkan, "Setelah itu, wahai Ali, bacalah doa berikut ini. والعزة والاكرام الجلال ذا والأرض السماوات بديع اللهم .عنى يرضيك فيما النظر حسن وارزقنى يعنينى لا ما أتكلف أن من وارممنى أبقيتنى ما أبدا المعاصى بترك ارحمنى اللهم

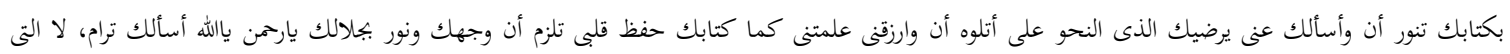

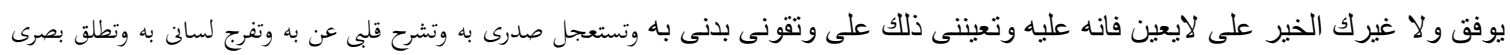
Ya Allah Tuhanku, rahmatilah aku agar dapat meninggalkan kemaksiatan-kemaksiatan sepanjang hidupku. Rahmatilah aku dari usaha habis-habisan yang tidak berguna bagiku. Karuniakanlah aku kemampuan 
program tahfizh saja karena dengan di lihat manfaatnya yang termaktub dalam hadis yang diriwayatkan oleh Ibnu Abbas, namun jika dilihat dari kacamata tasawuf, sholat ini bisa menjadi keharusan yang harus dilakukan oleh para penghafal al-quran, sebagai sarana permohonan khusus akan datangnya ridho Allah SWT agar selalu dimudahklan dalam menghafal dan menjaga kalam-Nya.

Jika dilihat dari teori ibnu khuldun ${ }^{5}$, maka awalnya impelemntasi sholat taqwiyatul hifd merujuk pada fann al-Tarikh tingkatan kedua dan ketiga Ibnu Khuldun, yaitu Fann memiliki

yang baik dalam memandang perkara yang membuat Engkau ridha kepadanya. Wahai Zat Yang Maha Mencipta langit dan bumi, wahai Zat Yang memiliki kegungan, kemuliaan, dan kejayaan yang tidak akan punah. Ya Allah, ya Rahman, dengan segenap kegungan-Mu dan kecemerlangam Zat-Mu, aku memohon engkau menetapkan hatiku di dalam menghafal Kitab Suci-Mu sebagaimana Engkau mendidikku. Karuniakanah aku kemampuan membacanya di atas jalan yang Engkau ridha kepadanya. Dengan perantaraan Kitab Suci-Mu, aku memohon, Engkau menerangi pandanganku, Engkau berikan kelancaran dan kefasihan lisanku, Engkau buka hatiku, Engkau lapangkan dadaku, Engkau gerakkan badanku, dan Engkau berikan kekuatan dan pertolongan atas semua itu. Sesungguhnya tidak ada yang memberikan pertolongan atas kebaikan itu selain Engkau. Dan tidak ada daya kekuatan kecuali dengan pertolongan Allah swt. semata, Zat Yang Maha Luhur lagi Maha Agung.")Beliau bersabda melanjutkan, "Wahai Ali, lakukanlah shalat ini tiga kali, lima kali, atau tujuh kali, niscaya dengan izin Allah dikabulkan. Sesungguhnya doa ini tidak akan menyalahi orang yang beriman sama sekali (yakni pasti dikabulkan)." Hadits tersebut diriwayatkan oleh at-Tirmidzi dalam Sunan-nya nomor 3641, al-Hakim dalam al-Mustadrak I/316. Ad-Daruqutni, dan Ibnu Sunni dalam Amal al-Yaum wa al-Lailah nomor 579. At-Tirmidzi berkata, "Hadits ini hasan dan gharib 'Asing'. Kami tidak mengetahuinya selain dari jalur alWalid bin Muslim. Daruqutni meriwayatkan dari Naqqasy (Muhammad bin al-Hasan bin Muhammad alMuqri), gurunya ad-Daruquthni. Ibnu al-Jauzi berkata, "Al-Walid penyembunyi cacat dan Naqqasy tertuduh." Al-Hakim berkata, "Hadits ini shahih menurut ketentuan Bukhari dan Muslim." Ibnul Sa'ad berkata, Al-Walid dapat di percaya (tsiqah) dan banyak haditsnya menurut al-Ijli dan Ya'qub bin Syaibah. “ Ibnu Sunni meriwayatkan dari Abdullah Muhammad bin Muslim dan Muhammad bin Karim bin Marwan dari Hisyam bin Ammar dari Muhammad bin Ibrahim al-Quraisyi dari Abu Shalih dari Ikrimah dari Abdullah bin Abbas. Dari jalur periwayatan ini tidak terdapat an-Naqqasy sebagaimana disebut oleh Ibnu al-Jauzi. Dengan jalur riwayat ini berarti terbantulah riwayat at-Tirmidzi, ad-Daruquthni, dan al-Hakim. Juga tertamballah kedhaifan dari arah tadhlisnya al-Walid. Hadits ini dengan demikian tidak jatuh dari nilai hasan. Sahabat Ali bin Abi Thalib setelah melakukan shalat kali ketujuh datang menemui Rasulullah saw. seraya berkata, "Kini aku mempelajari empat puluh ayat dan sepertinya Al-Qur'an tampak di depan mataku. Begitu pun jika aku mendengar hadits, tatkala aku mengucapkannya tidak ada satu huruf pun tertinggal." Selain suami Sayyidah Fatimah yang telah membuktikan keampuhan shalat tersebut, beberapa ulama juga telah membuktikannya dan mendapati kemujaraban. Al-Hafidzh Abul Hasan Ibnu Iraq berkata, “Telah memberitahukan kepadaku tidak hanya satu orang bahwa mereka mencoba melakukan shalat itu dan mereka membuktikan kemanjurannya secara nyata." Secara ringkas, tata cara shalat yang disebut dengan shalat Taqwiyatul Hifidz tersebut adalah sebagai berikut.a. Pada malam Jumat berniatlah melakukan shalat sunnah empat rakaat. b. Pada rakaat pertama membaca al-Fatihah ditambah surah Yaasin. Rakat kedua: al-Faatihah ditambah adDukhan. Rakaat ketiga: al-Faatihah ditambah as-Sajdah. Rakaat keempat:Al-Fatihah ditambah Tabarak (boleh dengan membawa dan melihat mushaf).c. Setelah tasyahud sebelum salam lakukanlah:1. Memuji kepada Allah, misalnya, dengan mengucapkan kalimat tahmid.2. Menghaturkan shalawat dan salam atas Nabi Muhammad dan para nabi yang lain, misalnya dengan membaca shalawat Ibrahimiyah.3. Mintakanlah ampun kepada orang orang yang beriman, misalnya membaca doa yang tersebut di dalam surah al-Hasyr: 10.4. Membaca doa sebagaimana tersebut diatas.d. Lakukanlah shalat ini barang tiga kali, lima kali, atau tujuh kali. http://bloggerislammu.blogspot.co.id/2010/05/urlhttpimg130.html.

${ }^{5}$ Nama lengkapnya adalah Waliuddin Abdurrahman bin Muhammad bin Abi Bakar Muhammad bin al-Hasan yang kemudian masyhur dengan sebutan Ibnu Khaldun. lahir di Tunisia pada 1 Ramadan 732 H./27 Mei 1332 M. adalah dikenal sebagai sejarawan dan bapak sosiologi Islam yang hafal Alquran sejak usia dini. Sebagai ahli politik Islam, ia pun dikenal sebagai bapak Ekonomi Islam, karena pemikiran-pemikirannya tentang teori ekonomi yang logis dan realistis jauh telah dikemukakannya sebelum Adam Smith (1723-1790) dan David Ricardo (1772-1823) mengemukakan teori-teori ekonominya. Bahkan ketika memasuki usia remaja, tulisantulisannya sudah menyebar ke mana-mana.Tulisan-tulisan dan pemikiran Ibnu Khaldun terlahir karena studinya yang sangat dalam, pengamatan terhadap berbagai masyarakat yang dikenalnya dengan ilmu dan pengetahuan yang luas, serta ia hidup di tengah-tengah mereka dalam pengembaraannya yang luas pula. Selain itu dalam tugas-tugas yang diembannya penuh dengan berbagai peristiwa, baik suka dan duka. Ia pun pernah menduduki jabatan penting di Fes, Granada, dan Afrika Utara serta pernah menjadi guru besar di Universitas al-Azhar, Kairo yang dibangun oleh dinasti Fathimiyyah. Dari sinilah ia melahirkan karya-karya yang monumental hingga saat ini. Nama dan karyanya harum dan dikenal di berbagai penjuru dunia. Panjang sekali jika kita berbicara 
tentang biografi Ibnu Khaldun, namun ada tiga periode yang bisa kita ingat kembali dalam perjalan hidup beliau. Periode pertama, masa dimana Ibnu Khaldun menuntut berbagai bidang ilmu pengetahuan. Yakni, ia belajar Alquran, tafsir, hadis, usul fikih, tauhid, fikih madzhab Maliki, ilmu nahwu dan sharaf, ilmu balaghah, fisika dan matematika. Dalam semua bidang studinya mendapatkan nilai yang sangat memuaskan dari para gurunya. Namun studinya terhenti karena penyakit pes telah melanda selatan Afrika pada tahun $749 \mathrm{H}$. yang merenggut ribuan nyawa. Ayahnya dan sebagian besar gurunya meninggal dunia. Ia pun berhijrah ke Maroko selanjutnya ke Mesir; Periode kedua, ia terjun dalam dunia politik dan sempat menjabat berbagai posisi penting kenegaraan seperti qadhi al-qudhat (Hakim Tertinggi). Namun, akibat fitnah dari lawan-lawan politiknya, Ibnu Khaldun sempat juga dijebloskan ke dalam penjara. keluar dari penjara, dimulailah periode ketiga kehidupan Ibnu Khaldun, yaitu berkonsentrasi pada bidang penelitian dan penulisan, ia pun melengkapi dan merevisi catatan-catatannya yang telah lama dibuatnya. Seperti kitab al-ibar (tujuh jilid) yang telah ia revisi dan ditambahnya bab-bab baru di dalamnya, nama kitab ini pun menjadi Kitab al-'Ibar wa Diwanul Mubtada' awil Khabar fi Ayyamil 'Arab wal 'Ajam wal Barbar wa Man 'Asharahum min Dzawis Sulthan al-Akbar.Kitab ali’bar ini pernah diterjemahkan dan diterbitkan oleh De Slane pada tahun 1863, dengan judul Les Prolegomenes d'Ibn Khaldoun. Namun pengaruhnya baru terlihat setelah 27 tahun kemudian. Tepatnya pada tahun 1890, yakni saat pendapat-pendapat Ibnu Khaldun dikaji dan diadaptasi oleh sosiolog-sosiolog German dan Austria yang memberikan pencerahan bagi para sosiolog modern. Karya-karya lain Ibnu Khaldun yang bernilai sangat tinggi diantaranya, at-Ta'riif bi Ibn Khaldun (sebuah kitab autobiografi, catatan dari kitab sejarahnya); Muqaddimah (pendahuluan atas kitabu al-'ibar yang bercorak sosiologis-historis, dan filosofis); Lubab alMuhassal fi Ushul ad-Diin (sebuah kitab tentang permasalahan dan pendapat-pendapat teologi, yang merupakan ringkasan dari kitab Muhassal Afkaar al-Mutaqaddimiin wa al-Muta'akh-khiriin karya Imam Fakhruddin ar-Razi).DR. Bryan S. Turner, guru besar sosiologi di Universitas ofAberdeen, Scotland dalam artikelnya "The Islamic Review \& Arabic Affairs" di tahun 1970-an mengomentari tentang karya-karya Ibnu Khaldun. Ia menyatakan, "Tulisan-tulisan sosial dan sejarah dari Ibnu Khaldun hanya satu-satunya dari tradisi intelektual yang diterima dan diakui di dunia Barat, terutama ahli-ahli sosiologi dalam bahasa Inggris (yang menulis karya-karyanya dalam bahasa Inggris)." Salah satu tulisan yang sangat menonjol dan populer adalah muqaddimah (pendahuluan) yang merupakan buku terpenting tentang ilmu sosial dan masih terus dikaji hingga saat ini.Bahkan buku ini telah diterjemahkan dalam berbagai bahasa. Di sini Ibnu Khaldun menganalisis apa yang disebut dengan 'gejala-gejala sosial' dengan metoda-metodanya yang masuk akal yang dapat kita lihat bahwa ia menguasai dan memahami akan gejala-gejala sosial tersebut. Pada bab ke dua dan ke tiga, ia berbicara tentang gejala-gejala yang membedakan antara masyarakat primitif dengan masyarakat moderen dan bagaimana sistem pemerintahan dan urusan politik di masyarakat.Bab ke dua dan ke empat berbicara tentang gejala-gejala yang berkaitan dengan cara berkumpulnya manusia serta menerangkan pengaruh faktor-faktor dan lingkungan geografis terhadap gejala-gejala ini. Bab ke empat dan kelima, menerangkan tentang ekonomi dalam individu, bermasyarakat maupun negara. Sedangkan bab ke enam berbicara tentang paedagogik, ilmu dan pengetahuanserta alat-alatnya. Sungguh mengagumkan sekali sebuah karya di abad ke-14 dengan lengkap menerangkan hal ihwal sosiologi, sejarah, ekonomi, ilmu dan pengetahuan. Ia telah menjelaskan terbentuk dan lenyapnya negara-negara dengan teori sejarah.Ibnu Khaldun sangat meyakini sekali, bahwa pada dasarnya negera-negara berdiri bergantung pada generasi pertama (pendiri negara) yang memiliki tekad dan kekuatan untuk mendirikan negara. Lalu, disusul oleh generasi ke dua yang menikmati kestabilan dan kemakmuran yang ditinggalkan generasi pertama. Kemudian, akan datang generasi ke tiga yang tumbuh menuju ketenangan, kesenangan, dan terbujuk oleh materi sehingga sedikit demi sedikit bangunan-bangunan spiritual melemah dan negara itu pun hancur, baik akibat kelemahan internal maupun karena serangan musuh-musuh yang kuat dari luar yang selalu mengawasi kelemahannya.ADA beberapa catatan penting dari sini yang dapat kita ambil bahan pelajaran. Bahwa Ibnu Khaldun menjunjung tinggi ilmu pengetahuan dan tidak meremehkan akan sebuah sejarah. Ia adalah seorang peneliti yang tak kenal lelah dengan dasar ilmu dan pengetahuan yang luas. Ia selalu memperhatikan akan komunitas-komunitas masyarakat. Selain seorang pejabat penting, ia pun seorang penulis yang produktif. Ia menghargai akan tulisan-tulisannya yang telah ia buat. Bahkan ketidaksempurnaan dalam tulisannya ia lengkapi dan perbaharui dengan memerlukan waktu dan kesabaran. Sehingga karyanya benarbenar berkualitas, yang di adaptasi oleh situasi dan kondisi. Karena pemikiran-pemikirannya yang briliyan Ibnu Khaldun dipandang sebagai peletak dasar ilmu-ilmu sosial dan politik Islam. Dasar pendidikan Alquran yang diterapkan oleh ayahnya menjadikan Ibnu Khaldun mengerti tentang Islam, dan giat mencari ilmu selain ilmuilmu keislaman. Sebagai Muslim dan hafidz Alquran, ia menjunjung tinggi akan kehebatan Alquran. Sebagaimana dikatakan olehnya, "Ketahuilah bahwa pendidikan Alquran termasuk syiar agama yang diterima oleh umat Islam di seluruh dunia Islam. Oleh kerena itu pendidikan Alquran dapat meresap ke dalam hati dan memperkuat iman. Dan pengajaran Alquran pun patut diutamakan sebelum mengembangkan ilmu-ilmu yang lain.” Ibnu Khaldun wafat di Kairo Mesir pada saat bulan suci Ramadan tepatnya pada tanggal 25 Ramadan 808 H./19 Maret 1406 M. Ia telah mencetuskan sejumlah teori dasar ekonomi modern jauh sebelum Adam Smith dan David Ricardo. Pada puncak kejayaannya, dunia Islam tak hanya unggul dalam bidang politik dan militer saja. Salah satu faktor penting yang menopang kemajuan Kekhalifahan Islam di era keemasan adalah sistem perekonomian yang kuat. Dengan menguasai ekonomi dunia, dunia Islam sempat menjadi adikuasa yang 
disegani.Dunia Islam di era keemasan memiliki sederet ekonom yang telah mencurahkan pemikirannya untuk membangun Kekhalifahan Islam. Salah satunya adalah Ibnu Khaldun. Sejatinya, ia adalah ilmuwan Muslim yang serbabisa. Namun, cendekiawan Muslim yang terlahir di Tunisia itu juga telah menyumbangkan pemikirannya tentang ekonomi.Ibnu Khaldun sudah mencetuskan berbagai macam teori ekonomi, jauh sebelum lahirnya para ekonom Barat yang diklaim sebagai bapak ekonomi seperti Adam Smith (1723-1790 M) dan David Ricardo (1772-1823). Ibnu Khaldun telah mencetuskan sejumlah teori dasar ekonomi modern yang hingga kini masih tetap berlaku. Teori-teori yang dicetuskannya merupakan hasil pemikiran yang terlahir dari hasil pengamatannya terhadap berbagai masyarakat yang kemudian dipadukan dengan analisis tajam dengan ilmu dan pengetahuan yang dimilikinya. Tak heran jika Ibnu Khaldun sempat didaulat sebagai guru besar Universitas al-Azhar Kairo yang dibangun Dinasti Fatimiyah.Selama mengabdikan dirinya di salah satu universitas tertua dan terkemuka di dunia itu, Ibnu Khaldun menulis sederet karya fenomel di bidang ekonomi, yang hingga kini masih menjadi obyek studi. Lantas apa sumbangan Ibnu Khaldun dalam bidang ekonomi?Ibnu Khaldun tercatat sebagai ekonom pertama yang secara sistematis menganalisis fungsi ekonomi, pentingnya teknologi, spesialisasi dan perdagangan ke luar negeri jika negara mengalami surplus ekonomi. Ia juga menekankan peran pemerintah dan kebijakan stabilisasi untuk meningkatkan output produksi serta pembukaan kesempatan kerja yang luas bagi masyarakat. Sang ekonom telah mempelajari ekonomi, sosiologi, ilmu politik dan berbagai ilmu lainnyauntuk memahami perilaku manusia dan sejarah. Dia mengungkapkan fakta bahwa spesialisasi merupakan sumber utama terjadinya surplus ekonomi. Pernyataan tersebut diungkapkan hampir tiga abad sebelum Adam Smith mengungkapkannya. Menurut Ibnu Khaldun, ketika ada suatu lingkungan yang kondusif untuk melakukan spesialisasi, maka sebaiknya pengusaha didorong untuk melakukan perdagangan dan produksi lebih lanjut. Dengan spesialisasi, seseorang bisa mendapatkan keuntungan lebih banyak dari usahanya. Dalam menjelaskan spesialisasi, Ibnu Khaldun mengatakan, "Setiap jenis kerajinan tertentu harus dihasilkan oleh orang-orang yang mahir dan terampil dalam membuat kerajinan tersebut. Semakin banyak berbagai subdivisi dari suatu kerajinan, maka semakin besar pula jumlah orang-orang yang harus mahir dalam membuat kerajinan tersebut."Para perajin, papar dia, harus mempunyai keahlian tertentu dan mereka dari hari ke hari semakin mahir dalam membuat kerajinan tangan. Pengetahuan mereka tentang kerajinan juga semakin banyak. Jika hal ini dilakukan dalam waktu yang lama, maka kerajinan akan berakar kuat dan bisa menjadi sumber mata pencaharian yang bagus. Menurutnya, spesialisasi berarti koordinasi dari berbagai fungsi dari faktor produksi. Sehingga, orang-orang akan mendapatkan kepuasan yang lebih dengan melakukan kerja sama dari pada mengerjakannya sendirian. Selain itu, koordinasi dan kerja sama dalam proses produksi harus ada dalam kewirausahaan berdasarkan kekuatan pasar.Ibnu Khaldun menganggap pekerja dan pengusaha sebagai pelaku ekonomi yang dihormati dalam masyarakat. Keduanya mencoba untuk memaksimalkan kegiatan mereka untuk mendapatkan upah dan laba. Baginya, keuntungan adalah motif utama dalam kewirausahaan. Sebab, dengan meraih banyak keuntungan diharapkan produksi bisa diperluas. Sedangkan, perdagangan berarti usaha untuk meraih keuntungan dengan meningkatkan modal, melalui pembelian barang-barang dengan harga rendah lalu menjualnya kembali dengan harga yang lebih tinggi. Laba merupakan nilai yang direalisasikan dari tenaga kerja. Namun nilai ini, yakni harga tenaga kerja, ditentukan oleh hukum penawaran dan permintaan. Poin ini tidak terjawab oleh Karl Marx dan para pengikutnya.Menurut Ibnu Khaldun, koordinasi, kerja sama dan arah faktor-faktor produksi dalam meningkatkan surplus ekonomi produktif, merupakan sebuah proses yang dilakukan oleh pengusaha. Tujuannya untuk mencari keuntungan. Para pengusaha menghabiskan waktu, tenaga dan modal untuk mencari barang dan jasa lalu menjualnya kembali dengan harga yang lebih tinggi demi memperoleh keuntungan.Ibnu Khaldun memuji prakarsa para pengusaha dalam kegiatan produktif mereka dan mereka pantas mendapat keuntungan dari usaha mereka yang berisiko. Bahkan Karl Marx dan David Ricardo kurang bisa memahami hal tersebut. Selain itu, sang ekonom Musim legendaris itu juga mengungkapkan sebuah teori ekonomi yang menyatakan harga barang dan jasa ditentukan oleh penawaran dan permintaan. Ketika suatu barang langka dan permintaan naik, maka harga menjadi tinggi. Para pedagang akan membeli barang di pusat barang tersebut diproduksi. Sehingga mereka bisa membeli dengan harga murah."Lalu mereka akan menjual barang tersebut di daerah yang barang tersebut masih dianggap langka serta tentu saja yang permintaan terhadap barang tersebut tinggi," papar Ibnu Khaldun. Dengan demikian, kata dia, para pedagang bisa menjual barangnya dengan harga tinggi dan mendapat laba yang lebih banyak. Namun ketika pada suatu tempat terdapat barang yang jumlahnya berlimpah, maka harga barang menjadi rendah. Ibnu Khaldun juga telah berhasil menunjukkan konsep biaya jangka panjang produksi. Ia juga terus menekankan kebijakan moneter yang stabil. Ibnu Khaldun benar-benar menentang kebijakan-kebijakan yang bisa memainkan nilai mata uang.Dia khawatir, pihak berwenang tergoda untuk mempermainkan nilai mata uang untuk mendapatkan keuntungan guna membangun istana dan membayar gaji para tentara bayaran. Jika pihak berwenang sampai melakukan hal itu, maka bisa terjadi inflasi dan penduduk akan kehilangan kepercayaan terhadap mata uang. Menurut Ibnu Khaldun, perlindungan terhadap daya beli uang itu harus dilaksanakan sebagai bentuk keadilan bagi masyarakat. Oleh karena itu, dia mengusulkan berdirinya badan moneter yang independen di bawah kekuasaan Hakim Agung, yang takut kepada Allah SWT. Sebab jika dibawah penguasa yang tidak takut Allah SWT, maka penguasa tersebut bisa mempermainkan nilai mata uang demi keuntungan pribadiPajak dalam Pandangan Ekonom LegendarisDalam sebuah risalah ekonomi yang 
Mazhab (metode) yang berharga, banyak faedahnya dan mulia tujuannya, dan tinggkatan yang ketiga yaitu tarikh adalah berita al-Ijtima' al-Insani (komunitas manusia) dan pada umummnya mencakup segala perubahan yang terjadi dalam peradaban karena watak peradaban itu sendiri.

Teori ketiga Ibnu kholdun bisa dibuktikan dengan perubahan diprogramkan sholat Taqwiyatul Hifdzi sebagai kegiatan wajib yang harus dilaksankan oleh santri yang sebelumnya tanpa adanya ketersangkutan dengan pengurus. ${ }^{6}$

Sealnjutnya jika di sholat Taqwiyatul hifzdi merujuk pada fann Ibnu Kholdun Dalam perspektif tasawuf, orang yang kesulitan menghafal atau ketika sudah hafal cepat hilang kembali, disebabkan karena banyak melakukan dosa dan maksiat kepada Allah SWT. Disinilah perlu adanya upaya yang harus dilakukan untuk mempermudah dan meningkatkan daya ingat serta memantapkan kemauan menghafal Al-Qur'an, salah satunya ialah melalui pendekatan-pendekatan rohani, selain tentunya aturan atau adab dalam menghafal Al-Qur'an yang terlebih dahulu harus dilaksanakan.

Pendekatan rohani inilah yang juga dipraktekkan oleh Pondok Pesantren Mahasiswa Syafi'ur Rohman Jember dalam bentuk implementasi sholat taqwiyatul hifz bi. Tujuan dilaksanakannya sholat taqwiyatul hifz̧hi ini selain mengamalkan sunnah Nabi Muhammad SAW, juga memohon kepada Allah SWT agar dimudahkan dalam proses menghafal Al-Qur'an dan menjaganya serta mengajarkan kepada santri untuk melatih diri dengan senantiasa bangun pagi untuk melaksanakan qiyamul lail sekaligus sholat taqwiyatul hif হ̧hi.

ditulisnya, Ibnu Khaldun pernah menulis dan membahas masalah pajak. Tulisan tersebut tercantum dalam bukunya yang fenomenal berjudul Muqqadimah. Tulisan tentang pajak termuat pada bagian faktor pemicu peningkatan dan penurunan pendapatan negara/kerajaan. Menurut Ibnu Khaldun, sebuah kerajaan yang baru saja didirikan, memungut pajak dari rakyatnya dalam jumlah yang tak terlalu besar.. Tetapi, ketika kerajaan tersebut semakin berkembang, maka pajak yang dipungut dari rakyatnya juga kian besar. Jika para pendiri kekaisaran/kesultanan mengikuti jalan agama, mereka akan menerapkan pajak yang disahkan oleh hukum Tuhan yang mencakup zakat, kharaj (pajak tanah), dan jizyah. Baik zakat, kharaj, maupun jizyah jumlahnya tidak terlalu memberatkan bagi masyarakat. Lagi pula pajak semacam itu sudah tetap dan tidak bisa dinaikkan. Ibnu Khaldun berpendapat, sebuah kerajaan yang dibangun dalam sistem suku dan penaklukan merupakan nomaden. Sebenarnya, kata dia, peradaban dibentuk untuk membuat para penguasa menjadi penuh kebaikan, kesabaran. Sehingga, kata dia, pajak dan kewajiban-kewajiban pribadi yang digunakan untuk memberikan pendapatan kepada kerajaan seharusnya tak memberatkan. "Jika pajak tak memberatkan, maka subjek pajak akan melaksanakan kewajiban mereka dengan penuh antusiasme," papar Ibnu Khaldun. Menurutnya, masyarakat akan giat bekerja untuk menyisihkan sebagian penghasilannya, guna membayar pajak yang ringan. Sehingga akan lebih banyak orang yang bekerja keras untuk meraih pendapatan. Hasilnya, orang yang membayar pajak akan meningkat dan pendapatan negara juga bertambah.Menurut dia, ketika sebuah kerajaan telah mengalami periode yang cukup panjang dan mulai menetap, tidak nomaden lagi, kaka kerajaan akan melakukan kegiatan bisnis. Kemudian kesederhanaan, tata krama, dan kesabaran mulai menghilang. Administrasi dituntut lebih detil.Anggota kerajaan semakin sejahtera dan penuh dengan kesenangan."Mereka hidup dalam kemewahan dan kebutuhan baru yang kurang penting mulai bermunculan," tuturnya. Hal itu, ungkap Ibnu Khaldun, mendorong kerajaan untuk menaikkan pajak pada semua golongan masyarakat, termasuk petani.Mereka ingin pajak membawa lebih banyak keuntungan bagi negara. Mereka juga memaksakan penjualan produk-produk pertanian ke kota-kota. Ketika pengeluaran untuk pembelian barang mewah semakin meningkat dalam pemerintahan, maka pajak pun pasti naik.Akibatnya, rakyat semakin terbebani dan itu membuat semangat para petani untuk bekerja semakin luntur. Sebab semakin banyak pendapatan yang mereka hasilkan, kian besar pula pajak yang harus ditanggung. Ketika petani membandingkan antara biaya pengeluaran dengan pendapatan. Mereka jadi semakin kecewa. Sehingga mereka meninggalkan pertanian. Hal ini menimbulkan penurunan pajak yang dikumpulkan oleh negara. Sehingga pendapatan negara berkurang."Oleh karena itu, sebaiknya negara atau pemerintah tidak menerapkan pajak yang terlalu tinggi kepada masyarakatnya supaya mereka giat bekerja," papar Ibnu Khaldun. Demikianlah salah satu sumbangan penting Ibnu Khaldun dalam bidang ekonomi. http://dani-hidayatdani.blogspot.co.id/2011/11/biografi-ibnu-khaldun-bapakekonomi.html

${ }^{6}$ Abdul Mustaqim Metode Penelitian Living Quran: Model Penelitian Kualitatif dalam Sobiron Syamsuddin, Metodologi Penelitian Living Qur'an dan Hadis. (Yogyakarta: TH Press dan Teras, 2007), h. 56. 
Manfaat sholat taqwiyatul hif $\not$ hi adalah untuk memperkuat daya ingat dalam menghafal Al-Qur'an, sholat taqwiyatul hif₹̧hi juga berisi doa atau permohonan kepada Allah SWT agar berkenan meningkatkan kekuatan memori otak, sehingga apa yang dihafalkan dengan susah payah tidak cepat hilang sebagaimana yang telah disampaikan oleh beberapa santri Pondok Pesantren Mahasiswa Syafi'ur Rohman Jember, yaitu Dwi Susanto, mahasiswa FKIP Bahasa Inggris Universitas Negeri Jember mengatakan:

"Kalau dari haditsnya, sholat hif̧̧̧i itu kan supaya mudab dalam menghafal AlQur'an'.'

Ahmad Abi Sodiq yang sedang kuliah di Fakultas Teknik Universitas Muhammadiyah Jember juga menambahkan :

"Ya kalau yang saya rasakan pribadi, biasanya setelah sholat

taqwiyatul hifahi, memorinya lebih mudah mengingat dan lebih mudah menghafalnya".

Selain dimudahkan dalam menghafal Al-Qur'an, sholat taqwiyatul hifžbi juga membantu para pelaksananya untuk memahami berbagai ilmu yang diajarkan di pondok pesantren maupun di kampus tempat para santri belajar keilmuan umum di bidangnya masing-masing. Salah satu contohnya adalah Khoiri Rofiki Abdillah yang sedang kuliah di jurusan Produksi Pertanian Politeknik Negeri Jember mengatakan :

"Kalau mengenai manfaat dari sholat ini banyak sekali mas, tapi yang saya rasakan pribadi, kita dimudabkan untuk memabami suatu ilmu, baik yang bitungbitungan ataupun yang lain, dengan kita faham akan ilmu itu, maka ilmu itu akan selalu kita ingat dan tidak akan mudah lupa.'

Begitu juga yang dikatakan oleh Muhammad Firdaus, mahasiswa Fakultas Hukum Universitas Negeri Jember ketika ditanya mengenai apakah sholat taqwiyatul bifz̧ bi juga berpengaruh dalam dunia akademik perkuliahan. Belia menjawab:

"Iya, kurang lebih bermanfaat juga untuk proses belajar. Karena secara logika begini: kita saja yang berusaba menghafal Al-Qur'an yang secara bentuk menggunakan bahasa Arab saja bisa, apalagi kita menghafal pelajaran-pelajaran yang dengan menggunakan bahasa Indonesia sendiri. Insya Allah berpengarub juga ke sistem belajar teman-teman. ${ }^{10}$

Dengan beberapa pendapat yang mengatakan dimudahkannya setelah melaksanakan sholat taqwiyatul hif̧̧ hi, tentunya dari kemudahan tersebut dapat membuahkan hasil dari apa yang telah ditanamnya, baik dalam menghafal Al-Qur'an maupun dimudahkan dalam memahami keilmuan perkuliahan. Hal ini merupakan bentuk atau contoh konkret setelah beberapa kali melaksanakan sholat taqwiyatul hifz $h i^{11}$

Hiya Beni Mahmudin, mahasiswa FKIP Biologi Universitas Negeri Jember mengatakan:

"Saya sib biasanya menghafalkan Al-Qur'an setengah halaman perhari mas, mungkin cuma lama menghafalnya, kalau sebelum sholat

taqwiyatul bif̧̧ hi itu mungkin butuh waktu beberapa jam. Tapi setelah

sholat taqwiyatul hif̨̌hi Insya Allah satu jam saja sudah lancar. ${ }^{12}$

Berbeda dengan Hiya Beni Mahmudin, Dwi Santoso mengatakan bahwa:

\footnotetext{
${ }^{7}$ Wawancara dengan Syifaur Rohman, 12 Desember 2017.

${ }^{8}$ Wawancara dengan Abi Shadiq, 13 Desember 2017

${ }^{9}$ Wawancara dengen Khoiru Rofiqi, 13 desember 2017.

${ }^{10}$ Wawancara dengan Muhammad Firdaus, 25 Desember 2017.

${ }^{11}$ Masagus \& Fauzan Yayan, Quantum Tabfidz: Metode Cepat dan Mudah Menghafal Al-Qur'an. (Jakarta: Emir, 2015), h. 46

${ }^{12}$ Wawancara dengan Beni Mahmudin, 26 Desember 2017.
} 


\section{"Sholat taqwiyatul bifz̧hi juga memudahkan dalam akademik perkuliahan, kan niatnya juga baik mas, Alhamdulillah setelah sholat tersebut, IP tidake kurang dari 3,5 setiap semester". ${ }^{13}$}

Selaras dengan Dwi Santoso, bahwa sholat taqwiyatul hif̧̧̌i juga membantu memudahkan dalam akademik perkuliahan. Khoiri Rofiki Abdillah "Digampangkan dalam urusan belajarnya mas, jujur saja saya ini nggak pernah belajar, belajar saat pas waktu mau ujian saja, tapi Alhamdulillah oleh Allah masih diberi kemudahan dan nilai yang bagus. Dalam menghafal Al-Qur'an biasanya sehari cuma dapat lima baris saja mas, tetapi setelah sholat taqwiyatul hif żhi dan itupun terpotong waktu kuliah juga, saya dapat menghafal satu halaman penuh. ${ }^{14}$

Seiring rajinnya santri dalam melaksanakan sholat taqwiyatul hif zhi, maka apa yang diusahakan dalam menghafal Al-Qur'an akan semakin dimudahkan dalam memperlancar Al-Qur'an yang telah dihafal oleh santri tersebut. Hal ini sudah dibuktikan oleh beberapa santri yang rajin setiap minggunya melaksanakan sholat taqwiyatul hif $2 h i^{15}$ Maka terlihat jelas bahwa santri yang sering muroja'ah hafalannya dan melaksanakan sholat taqwijatul hifz̧hi maka hafalannya akan diberi kelancaran oleh Allah SWT sesuai usaha yang dilakukannya. Berbeda dengan santri yang jarang sekali melaksanakan sholat taqwiyatul bifžbi, maka hafalannya sesuai dengan usaha yang didapat, yaitu lemahnya hafalan Al-Qur'annya. Hal tersebut sesuai dengan penjelasan ustadz Abdul Rozaq dalam wawancaranya :

"Menurut pengamatan saya selama menyimak setoran hafalan santri,

Insya Allah tidak ada santri yang jarang sholat taqwiyatul bifz̧bi tapi

hafalannya lancar ataupun sebaliknya yaitu santri yang rajin sholat taqwiyatul hifz. hi tapi hafalannya mbulet. ${ }^{16}$

Muhammad Firdaus, selaku santri Pondok Pesantren Mahasiswa Syafi'ur Rohman Jember juga menambahkan demikian selaras dengan jawaban ustadz Abdul Rozaq, bahwa: "Yang benar-benar menjaga hafalannya Insya Allah menjaga sholat taqwiyatul hifžbi-nya juga."

\section{Kesimpulan}

Dalam kajian ini lebih pada kajian yang bersifat empiris sehingga ada tiga hasi penelitian pertama bahwa konsep sholat likhifdil Quran menjadi sarana dalam membuat hafalan lancar, kedua bahwa ritual ini hanya sebagai penjjaga hafalan Al-quran dan ketiga dalam kajian ini sangat terlihat Living Al-Quran dalam bentuk menjaga hafalan Al-Quran.

\section{DAFTAR PUSTAKA}

An-Nawawi, Imam Abu Zakaria Yahya bin Syaraf, (2014). At-Tibyan: Adab Penghafal Al-Qur'an, Solo: Al-Qowam.

Chairani, Lisya \& Subandi, (2010). Psikologi Santri Penghafal Al-Qur'an: Peranan Regulasi Diri, Yogyakarta: Pustaka Pelajar.

Herry, Bahirul Amali, (2012). Agar Orang Sibuk Bisa Menghafal Al-Qur'anYogyakarta: Teras Media

Masagus \& Fauzan Yayan (2015). Quantum Tabfidæ: Metode Cepat dan Mudah Menghafal AlQur'an. Jakarta: Emir.

\footnotetext{
${ }^{13}$ Wawancara dengan Dwi Santoso awal januari 2018

${ }^{14} \mathrm{Ibid}$

${ }^{15}$ Irsyadi, Najib. 2014. Tradisi Sholat Al-Hif̧̧hi Bagi Penghafal Al-Qur'an di Ponpes Raudhah Tabfizh Al-Qur'an "BAITUL AZHAR” Amuntai, Kalsel, (Yogyakarta: UIN Sunan Kalijaga, 2014), h. 35.

${ }^{16}$ Wawancara dengan Abdul Rozak Awal Januari 2018.

${ }^{17}$ Wawancara dnegan Muahad Firdaus Desember 2017.
} 
Mustaqim, Abdul, (2007). Metode Penelitian Living Quran: Model Penelitian Kualitatif dalam Sobiron Syamsuddin, Metodologi Penelitian Living Qur'an dan Hadis, Yogyakarta: TH Press dan Teras.

Irsyadi, Najib, (2014). Tradisi Sholat Al-Hifzhi Bagi Penghafal Al-Qur'an di Ponpes Raudhah Tabfizh Al-Qur'an "BAITUL AZHAR" Amuntai, Kalsel, Yogyakarta: UIN Sunan Kalijaga.

\section{Link Internet}

http://bloggerislammu.blogspot.co.id/2010/05/urlhttpimg130.html

http:/ / dani-hidayatdani.blogspot.co.id/2011/11/biografi-ibnu-khaldun-bapakekonomi.html

\section{Data wawancara}

Wawancara dengan Syifaur Rohman, 12 Desember 2017.

Wawancara dengan Abi Shadiq 13 Desember 2017

Wawancara dengen Khoiru Rofiqi 13 Desember 2017.

Wawancara dengan Muhammad Firdaus 25 Desember 2017.

Wawancara dengan Beni Mahmudin 26 Desember 2017.

Wawancara dengan Dwi Santoso awal Januari 2018

Wawancara dengan Abdul Rozak awal Januari 2018.

Wawancara dnegan Muahad Firdaus Desember 2017. 

